DOI: 10.2478 /aussoc-2020-0002

\title{
About the System of Prejudices among the Hungarian Youth in Romania, Slovakia, Serbia, and Ukraine
}

\author{
Andrea SÓLYOM \\ Sapientia Hungarian University of Transylvania \\ Cluj-Napoca, Romania \\ solyomandrea@uni.sapientia.ro
}

\begin{abstract}
This study is focused on the relationship between the youth and other social groups based on the data of the GeneZYs 2019 study. The study asked 15-29-year-olds from four countries regarding how appealing or unappealing they feel 24 different social groups. Research results show that several social groups, e.g., homosexuals, migrants/refugees, skinheads, drug users, are especially perceived as relatively repulsive/distasteful by the youth of the studied countries. Starting from theoretical and empirical antecedents, the author presumed that the low level of openness among the youth could be explained by several factors such as socio-demographic background, religiosity, value orientation, and sources of information. Based on empirical results, the author takes an analytical approach on the population under study. The goal of the study is to exceed the level of a partial analysis and to explore a typology while redefining the relationship between the motivation factors of prejudices. The hypotheses were partially confirmed. Compared to the author's expectations, the typology of young people based on their attitudes towards otherness seems to be harder to explain. Three groups were identified: a smaller one which feels others being appealing, a larger one with a neutral attitude towards others and which sympathizes less with Hungarian groups than the average, and a mediumsized third group which dislikes otherness. From the characterization of the groups, one can discover that among those who dislike otherness, the overrepresented categories are: men, young people from rural areas, those who finished secondary education level, those economically active, young people from Ukraine, atheists, those who did not study abroad, people who suffered from discrimination experiences, young people with regional Hungarian and/or Hungarian identity, people who are not satisfied with the national economy and interethnic relations, and those who see the future in a pessimistic way.
\end{abstract}

Keywords: prejudices, youth/young people, minorities, typology analysis 


\section{Introduction}

The study of prejudices with academic objectivity is very difficult because beliefs of everyday life can hardly be described by scientific terms. Therefore, a prejudice study does not exist without evaluation; such a study usually supposes that there is somebody who can make the proper judgment. People with prejudices thus become stigmatized; they turn into the object of the prejudice (Erôs 2005: 374). Erôs's idea highlights one of the main methodological problems of the prejudice studies, which is rarely reflected by the majority of authors.

According to the results of sociological studies on youth from the past few years, the social distance perceived by Hungarians outside Hungary towards different other groups is relatively large (Papp Z. 2008; Sólyom 2007, 2012, 2013). Several surveys conducted in the past two decades confirmed that the low level of tolerance can be caused by various factors, i.e.: value preferences, religiosity, models of interpersonal communication, and media consumption factors (Balassa 2007; Molnár 2011; Murányi-Szabó 2007; Örkény-Váradi 2010; Sólyom 2009, 2011).

The present study tries to answer whether there are differences between the 15-29-year-old Hungarian young people living in different countries (i.e. Romania, Serbia, Slovakia, and Ukraine) regarding their acceptance or rejection of other social groups and their relation to otherness.

The ethnic composition of the studied societies is changing, so that analysing the relation to otherness and its explanatory background has a permanent relevance. Additionally, in the ever more diversified societies, it is necessary to redefine the coexistence patterns. According to the demographical projections until 2032, in certain settlements of Harghita and Covasna counties from Romania - but probably also in some other regions outside Hungary -, the proportion of Gypsies will be close to $50 \%$ of the entire population, while among first-grade pupils it will reach $50-80 \%$ (Csata-Kiss 2007). Thus, young generations' relation to otherness is extremely important during the expected changes in ethnic composition. The author suggests that the Hungarian youth from the Szeklerland region (i.e. Harghita and Covasna counties from Romania) can be characterized by a minority status compared to the population of the country, but inside the region they experience their identity as a majority, which does not seem to favor their solidarity towards otherness. The results of the surveys conducted in different periods contradict each other in this regard (Kiss et al. 2008: 16, Sólyom 2013).

The socializing role of the media in Hungary does not enhance solidarity among different minorities. In the last few years, one can easily identify signs of dispersion of opinions related to migrants/refugees and homosexuals. Some local events from Harghita and Covasna counties can be quoted here as examples for the manifestations of intolerant attitudes towards otherness: e.g. in the summer of 2016, a scene was staged at the local festival of the village of Kommandó (Comandău, 
Covasna County), or a video was recorded at the carnival in Oroszhegy (Dealu, Harghita County) in 2017. ${ }^{1}$ Such materials showcase how pupils are acting in scenes where the rejection of refugees takes place. ${ }^{2}$ Fragmentation of the political élite and its contradictory standpoints regarding the regulation of domestic partnership among same sex people is another local, regional characteristic.

In the meantime, due to the politics of the Hungarian government - which supports Hungarians outside Hungary -, there are growing chances for Hungarians outside Hungary to be rejected by homeland Hungarians. In Hungarian-Hungarian relations, this social distance is not a novel phenomenon. The auto- and hetero-stereotypes "have been abundantly fuelled by the labelling of Hungarians from Transylvania as Romanians; this has been experienced since the regime change, and it can be outlined in connection with the failed referendum of 2004, or it can be illustrated even with facts pertaining to current politics" (Papp Z. 2012: 110 - author's translation). The institution of double citizenship enriches the identity with new elements, or even a new identity is about to take shape, but "these will be part of the minority identity structure: although they are present as possibilities, they do not entirely overwrite the former approaches. As a consequence, the bilateral Hungarian-Hungarian prejudice system subsists" (Papp Z. 2014: 149 - author's translation). Therefore, double citizenship does not yield adjustment in everyday experiences and perceptions. Furthermore, the young generation will probably get involved into situations (e.g. by learning, working abroad) where they can gain personal experiences about otherness. Based on the simplified version of the contact hypothesis, these personal experiences will probably moderate the relation to otherness originating from the stereotypes learnt from family, school, peer-group, and mass media.

The present study compares the prejudices of young adults living around Hungary. In November 2015, 2,697 Hungarian young adults were asked to answer on a scale from 1 to 5 as to what extent they find antipathetic or sympathetic the members of 24 different groups. In the first part of the study, certain theoretical, methodological, and empirical approaches will be in focus, which can be used as starting points in the second part, during the analysis.

\section{Theoretical and Empirical Antecedents}

\section{Tolerance, Prejudices, and Social Distance: Local Particularities}

We can find multiple approaches about the relationship of the social distance and prejudices. According to one of them, social distance can be perceived as

1 See the audiovisual material AV1 from 00:58 to 03:58.

2 Several articles appeared in the mass media about these events; see the audiovisual materials: AV2, AV3. 
an indicator of the level of prejudices. "The main psychological condition of the prejudicial way of thinking is the delimitation of own group (in-group) and outgroups. (...) The social distance between the own group and the different outgroups can be determined based on the interactions between the group members, and thus one can conclude about the level of prejudices towards out-groups and the level of discriminative orientations" (Fábián-Sik 1996: 382; author’s translation). A study on the methodological problems of prejudice studies from Hungary and the international literature draws attention to the fact that "the terms of prejudice, discrimination, social distance, xenophobia, or hostility towards Gypsies are not separated from one another" (Erôss-Gárdos 2007: 20; author's translation).

Prejudices, stereotypes, and generalized everyday life experiences can be enumerated among the factors behind social distance, which serve to measure tolerance. However, the answers given to hypothetical situations are not suitable to identify these.

On the relation towards Gypsies and Jews, several Hungarian studies confirmed that regarding the former the society can be characterized by a homogenous attitude, while in the latter case the classic social psychological approaches can be applied, i.e. prejudices correlate with political orientation, value system, and party preferences (Erős 2005). Attitudes towards Gypsies generally differ from attitudes towards other minorities because in the Hungarian society there is a "consensus" in this regard, independently from the respondents' level of education (Székelyi et al. 2001: 33). Based on the results of the 2007 Carpathian Panel, prejudices about Gypsies do not differ even by political preferences (Papp Z. 2009). Anti-Semitism does not correlate with social stratification; it is independent from financial and cultural background or socio-economic status (Balassa 2007, Kovács 2014, Hann-Róna 2015).

These tendencies are perhaps valid among the Hungarian youth from the neighbouring countries as well, and the sympathy/antipathy towards Gypsy and Jewish social groups will probably be independent from the socio-demographic background.

In 2015, a sample group of the 16-29-year-old NEET (not in employment, education, or training) youth was surveyed in two southern developmental regions of Romania about negative discrimination as a factor which threatens social integration. Reference made to the study is justified by the procedure adopted during the analysis. The authors adopted three indicators to measure the acceptance/rejection of eight different social groups. They counted the number of situations when respondents behaved tolerant and intolerant towards the listed groups. The indicator of social distance measured the average of the rejection situations towards the groups; based on these, intolerant, tolerant, and so-called neutral attitudes were delimited. Young adults with a medium level of qualification were less acceptant than those with a low level of education; boys, rural dwellers, those without children and with a higher income were more dismissive than the others (Plăeşu et al. 2015: 83-84). 


\section{The Relation between Communication, Information, Value Preferences, and Prejudices in the Analyses}

Molnár studied the role of socio-cultural characteristics and media consumption played in prejudicial attitudes on a national sample of high school students from Hungary. Her results fit in the former empirical antecedents: "boys who live in a less urbanized area come from a family with a low level of education, study in vocational schools, and are not religious seem to be more intolerant towards their peers belonging to different out-groups" (Molnár 2011: 79 - author's translation). Related to the age, the author found the same tendency as Bădescu and his coauthors among Romanian high school students: the level of rejection towards other groups is intensified among younger generations (Bădescu et al. 2010). Based on these analyses, it is possible to formulate hypotheses about the linkage between prejudices on the one hand and the socio-demographic factors, religiosity, and media consumption on the other.

Sőrés explored the role of the Internet in shaping the groups of extreme right among the university students in Debrecen. She identifies a committed group and an inquisitive one that differ from each other based on origin, media consumption, value system as well as their relation to otherness. Boys who come from families with low educational level, prefer financial values, consume mass media intensively, and definitely reject otherness belong to the committed group. The inquisitive group comprises young people who come from families with a higher level of education who prefer postmaterialistic values and who can be characterized by openness towards others; they integrate only certain elements of the extreme right into their value system (Sőrés 2012). Partially similar results were found by Varga among university students in Debrecen (Varga 2012). Value system, political orientation, and the use of the Internet as factors contributing to the relation to otherness will also be analysed in this study.

\section{Methodological, Analytical Considerations}

Based on Erôs's (2005) approach, this chapter lists a few methodological pitfalls which we may face while studying prejudices, and it will focus on certain studies whose methodological apparatus is going to be considered during the analysis. Certain methodological problems are generally valid for other studies as well, i.e. the limitations of the questionnaire as a measuring tool in studying actions since answers given to hypothetical situations cannot identify everyday life experiences, the so-called conformity of the respondents during a survey, etc. 


\section{Trap Situations}

The majority of classic theories are normative, but descriptive approaches have also emerged recently (Erős 2007). The difference between the two types of approaches is not so striking - certain authors use both without reflection. According to some psychological approaches, prejudices originate from the human nature: "Stereotypes are cognitive maps that help us simplify our highly complex social world. (...) Prejudices, after all, guarantee that 'we' will compare favourably to 'them'” (Shields 2014: 21). Thus, prejudices help "navigation" but hinder cohabitation, cooperation and widen the gaps inside the society.

Based on the empirical results of the international literature of social psychology (Brown 1995 - qtd by Erős 2005), the hard-line, firm stereotypes with negative connotations became off-colour; they have partially disappeared from the communication and got into the category of taboo. But they have not necessarily been refined. They were switched to softer, latent, and encoded attitudes, which are hard to measure by the former tools (Erős 2005, Kovács 2007). In Hungary, based on studies realized during the first decade of the 2000s, it looked like - compared to the nineties - the manifest rejection of the Gypsies decreased after 2000, and, besides the "old-style" one, there appeared a more presentable, latent rejection (Balassa 2007). So, in the nineties and the early 2000s, there emerged a politically correct discourse, which, however, did not mean a change of attitudes, but taboos aggravated their measurement. At almost the same time, starting from the 2010s, mass media channels have been telling about series of murders against Gypsy people. In 2008 and 2009, nine murders took place in four settlements of Hungary, which resulted in six deaths and the injuries of further fifty people (Szénási 2016). In the last decade, reverse tendencies can be noticed both in Hungary and in certain other areas of the European Union and in the United States of America: the presentable discourse is changed by a politically lesser correct one. It is questionable to what extent was the studied population affected by these changes.

\section{Social-Historical Impregnation and Context}

Beréti and Tóth set out from the results of an international comparative phone-based survey conducted in 2008 in eight countries, which concentrated on six prejudice types (Zick et al. 2011). The strongest prejudices were measured in Poland and Hungary, and, while in Europe the rejection of other groups increases with age, the rejection of otherness in Hungary is the most accentuated among the 16-22-yearold youth (Beréti-Tóth 2014). The authors tried to explain the dispersion of the mentioned attitude on the basis of the historical differences between the western and eastern part of Europe, especially in the light of the events of the $20^{\text {th }}$ century. However, finally, they explained the attitudinal differences between eastern and 
western countries with the specific life conditions from these countries. The Hungarian coordinators of the comparative study agree with Bergman in that "the attitudes are determined by social memory independently from the proportion of the Jews in the given societies" (Örkény-Váradi 2010: 35 - author's translation). Several other studies concluded that the heritage of feudalism and socialism, the dictatorships and democracies as socialization contexts favour trust towards other people and institutions, responsibility, risk-taking, and autonomy perceptions (Mihăilescu 1996, Voicu 2006). However, Székelyi and her co-authors contradict the idea according to which in the case of changing the life conditions the differences in the attitude of the eastern and westerns societies are relatively moderate. "One can barely hope for the growth of general tolerance in a society, even upon the completion of illusory goals such as increased general cultural/educational level of the improvement of life conditions" (Székelyi et al. 2001: 35 - author's translation).

György G. Márkus started out from the same already mentioned international comparative study conducted in 2008, and he similarly considers the social historical impregnation as a potential explanation of prejudices. In addition, he draws attention to the fact that prejudices "superimpose on the political gaps" (G. Márkus 2012: 80 - author's translation). Based on the result of G. Márkus (2012) and Sőrés (2012), we assume that the political orientation and the value system are connected to the perception of otherness, and so rightists and those who prefer financial values perceive other ethnic communities as more unappealing.

A striking rejection of migrants is especially characteristic of citizens with fewer personal experiences with strangers. The usual trend is that personal experiences do not enhance but demolish stereotypes (contact hypothesis) (Örkény-Váradi 2010). It is questionable to what extent this tendency can be sustained after the wave of refugees experienced by Hungary between 2014 and 2016 and its representation in the media. Örkény and Váradi identify countries characterized by structural prejudices and value-guided, ideology-based prejudices. They analyse the differences between such countries based on the level of general prejudices and the dimensions of prejudices. The differences can be strongly captured by delimitating a strongly prejudiced, a medium, and a prejudice-free group, and then they tone the picture: based on the four dimensions of the prejudices, they divide the inhabitants of these countries into five cluster groups ${ }^{3}$ (Örkény-Váradi 2010: 31 - author's translation). The mentioned procedures can also be useful in comparing the Hungarian youth from the neighbouring countries.

The results of a national survey from Romania conducted in 2012 among 1,691 Romanians (of which 703 were from Transylvania) show that less Romanians from Transylvania than from the other regions support the measures adopted by the

3 1. prejudicial with all the groups; 2. strong anti-Semitism, average xenophobia, and poor racism; 3. medium; 4. only xenophobe; 5. without prejudices (Örkény-Váradi 2010: 40 - author's translation). 
Hungarian state to help Hungarians in Romania (Kiss-Barna 2013: 65-67). Based on the attitudinal difference between Romanians from Transylvania and the whole population, we can presume that multicultural environments, personal experiences, chances of contact between groups facilitate acceptance on the individual level, but on the group level they can even enhance prejudices and stereotypes, depending on competition, context, and minority/majority status (Balassa-Kovács 2010).

According to the classical version of the contact hypothesis, "only the cooperative and competition-free relations of actors with equal status and those who are not role-guided have impact on reducing prejudices, especially when the relation receives normative confirmation/reinforcement from important resources institutions, personalities, based on widely accepted norms" (Balassa-Kovács 2010: 100 - author's translation).

Regarding the empirical testing of the contact hypothesis, we can quote the study of Chen, which analysed the role of study experiences in the perception of social distance of American students who had spent a period of time in China. The study confirmed that learning about other cultures, everyday interactions, and personally experienced diversity accompany a more inclusive and open attitude (Chen 2007). Another study that focuses on contact hypothesis was realized in the spring of 2013 as a phone-based survey among the 13-18-year-old youth from five Balkan countries. Milosevic analysed the social distance perception of youth towards five groups. The most rejected groups proved to be the sexual and ethnic minorities, and the least ones were people with disabilities and the poor. Youngsters from Kosovo were the least open, while the youth from Montenegro and Bosnia and Herzegovina were the most open-minded. "A positive effect of the contacts on social behaviour was confirmed towards different groups: homosexuals, psychiatric patients, racial and ethnic minorities" (Herek-Capitanio 1996 - qtd by Milosevic 2015: 416). Further research made a typology of contacts based on the quantity and quality of interactions, i.e.: "time spent accompanied by out-group friends, disclosure to outgroup friends, inclusion, friendship circle, number of friends, or feeling closeness to out-group friends” (Davies et al. 2011 - qtd by Milosevic 2015: 416).

Several empirical analyses from the international literature confirmed the role of contacts in information flow, in the out-groups' heterogeneity, and in forming the attitudes, trust, opinions, and actions. In more conservative societies, it is more usual to see minority groups as homogenous and to prefer more repulsive attitudes. The cognitive change provoked by interactions can reduce rejection. "In postwar societies, it is expected that national identification could be associated with in-group favouritism and distance from minority groups" (Milosevic 2015: 417). The studied youth from the Balkan regions confirmed the tendencies of the international literature. "Frequent contacts with members of minority groups were proved to have direct and indirect positive correlation mediated through perceived out-group heterogeneity with increased social acceptance, while stronger national identification correlated 
negatively with social acceptance of minority groups" (Milosevic 2015: 424). In the present study, the number of friends on Facebook and their heterogeneity can be used for testing the contact hypothesis although the number of friends is not an indicator of friendships, but it indicates somehow the network of the youth. The strength of national identity can be correlated with prejudices.

The already mentioned study of Balassa and Kovács delimits the role of context and contacts in Hungarian settlements with mixed population and on a national sample of adults. According to their results, the context enhances the impact of contacts - namely, personal relations among members of different ethnic groups reduce prejudices, and this impact will be enhanced if the relations are formed in an ethnically mixed settlement (Balassa-Kovács 2010: 110). They concluded that mixed environments and personal relations both enhance sympathy towards minorities but do not reduce the willingness of using stereotypes. The use of positive stereotypes does not contribute to the demolition of group borders, rather it facilitates increasing social distances (Balassa-Kovács 2010: 110-111). It is a question to what extent these phenomena observed in Hungarian settlements with mixed population characterize the regions of my study. A settlement with mixed population represents an entirely different group of study in places with double identity (Hungarian and Swabian, Hungarian and Slovak) and where everybody uses the Hungarian language as compared to places where group borders are more accentuated.

\section{Structural Factors}

In analysing the level of xenophobia occurring during the 1990s in Hungary, Csepeli and Sik identify three types of behaviour: acceptant, dismissive, and selective acceptant. They highlighted the role of incorporated and objectified cultural capital in forming the mentioned attitudes (Csepeli-Sik 1995 - qtd by Fábián-Erős 1996). In a study on causality connections of hostility to Gypsies, Fábián and Erős underlined authoritarianism as a factor transmitting the sociodemographic characteristics. Based on their research results, religiosity favours more tolerant attitudes among the youth (Fábián-Erős 1996). Murányi confirmed not only the connections between prejudices and religiosity but the connections between prejudices and belonging to a certain denomination. However, such relations appeared sometimes inversely, inconsequentially in different studies. On the whole, the studied Reformed youth are more prejudicial to otherness than their Catholic peers. According to the author, this can be explained by the regulative and permissive role of the denominations (Murányi 2004).

Balassa tries to answer why respondents reject certain groups while they accept others. She builds up explanatory models by regression path analysis that helps researchers to find out what combination of factors motivates prejudicial attitudes in the first place. She made use of discrimination analysis to explain the differences 
between the groups created by cluster analysis. She concluded that those who discriminate against each group can be characterized by a low social status, anomie, social frustration, and lack of information. The rejection of only certain groups is ideologically embedded in some cases; in other situations, the reason is dissatisfaction with the own situation (Balassa 2007).

\section{Hypotheses}

The origins of the hypotheses were discussed during the theoretical and empirical antecedents presented above. In the international socio-psychological literature, the study of connections between authoritarianism and prejudices had a significant carrier in the past half century. Csepeli, Fábián, and Sik analysed the role of four main factors in the acceptance/rejection of foreigners and Gypsies: "1. socio-demographic variables; 2. socio-psychological variables; 3 . contextual variables regarding migration; 4. political variables" (Csepeli et al. 2006: 472 author's translation). Similar to this and with regard to the first group of factors, the first hypothesis of the present study suggests that, besides age, level of qualification, and income, settlement type and occupation can also be connected with the relation to other groups. From the second group of factors, a separate hypothesis will be formulated about religiosity; the subjective material situation is classified into the socio-demographic background. Regarding value preferences, a separate hypothesis will be similarly stated. Several studies confirmed that dissatisfaction with the macro-, micro-economic and the political situation, i.e. the so-called social frustration can be connected to changes in the acceptance of otherness (Csepeli et al. 2006, Balassa 2007). Similarly, the study on connections between prejudices and anomie, alienation, and loneliness may be regarded as a classic one. Political interest, evaluating how democracy functions, and one's own political orientation can be related to the acceptance of other groups. Based on the model tested among the adult population of Hungary, only those with the highest level of qualification proved to be tolerant (both in terms of manifest and latent xenophobia). Furthermore, "the autonomous role of dissatisfaction, certainly attached to the relative deprivation, was demonstrable in developing xenophobia" (Csepeli et al. 2006: 481 - author's translation).

The hypotheses of the study are the following:

H1. The differences in prejudices can be motivated by the socio-demographic factors - material and cultural background, age, and settlement type. Those coming from less favourable material and cultural background, from rural settlements and younger respondents probably accept less otherness.

H2. Acceptance of otherness could be associated with institutional religiosity: religious young people are more tolerant. 
H3. Media consumption, online communication, and otherness: use of new information sources favours selective perception.

H4. Interest in politics, evaluation of how democracy functions, own political orientation, and acceptance of otherness are connected to each other: those who show interest towards politics and who are rather satisfied with the way how democracy functions perceive the other groups as more appealing, whereas those who place themselves to the right perceive the other groups as being unappealing.

H5. The value system and the prejudices are in correlation with each other: those who prefer postmaterial values perceive the other groups as more appealing, while those who prefer material values perceive the other groups as more unappealing.

H6. Contact hypothesis: the experiences from abroad lead to a more positive attitude, and the ethnic heterogeneity of the online acquaintances favours an acceptant relationship with otherness.

\section{Analysis and Discussions}

The present study compares the prejudice of youth living around Hungary based on the dataset of the GeneZYs 2015 study. In November 2015, 2,697 Hungarian young people were asked on a scale from 1 to 5 to what extent the members of 24 different groups are antipathetic and sympathetic for them. The groups are enumerated in Table 5 included in the Appendix. There are groups perceived as deviant, majority nations, Hungarians from Hungary and the neighbouring countries, other nations and minority groups. The analysis was based on multivariate methods, i.e. regression analysis, cluster analysis, and discriminant analysis.

\section{Prejudices Based on Socio-Demographic Characteristics (H1)}

The most unappealing groups are judged by society as being deviant; this includes homosexuals, drug consumers, skinheads, and refugees/migrants. Secondly, the politicians, the upstart, and Gypsies are perceived as unappealing. At the same time, the perception of the most ungrateful groups is the most heterogeneous based on the standard deviations of every control variable. Of the entire sample, the Hungarians from Transylvania are the most sympathized. On the second place, we can find the Hungarians from Hungary followed by Hungarians from other neighbouring countries.

We can find regional differences among the youth. However, based upon this, we can only make a careful statement that the Hungarian youth from certain countries acts more openly towards otherness. It seems that the young people of Serbia are the most tolerant, but further analysis, evidence, and explanatory models would be necessary in order to support this assertion. 


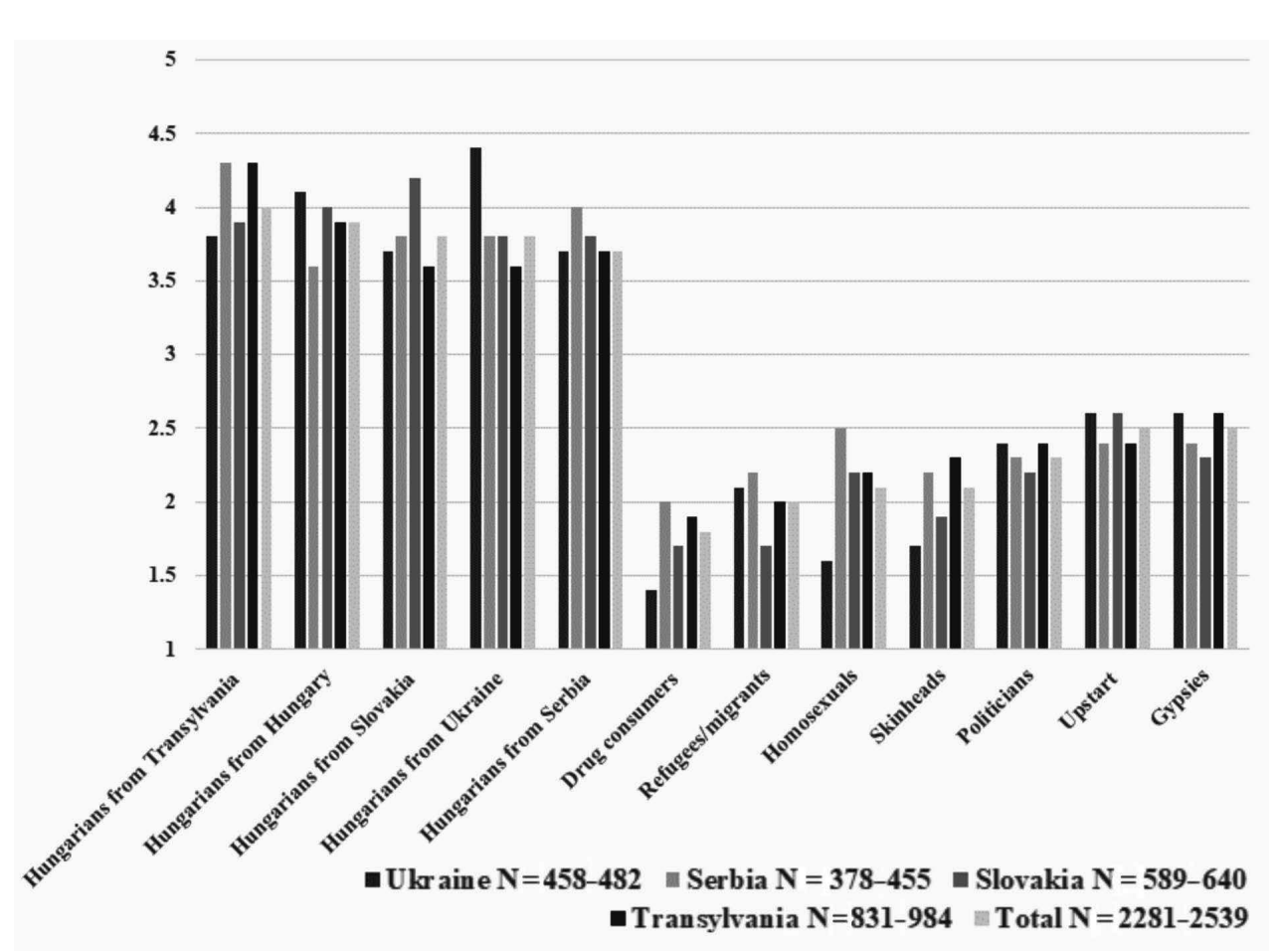

Source: author's computation based on the dataset of the GeneZYs 2015 study

Figure 1. The most appealing and the most unappealing groups in the perception of young people (means, 5 - very sympathetic, 1 - very antipathetic)

In the following, we will discuss the results of the test of the hypotheses on the entire sample, not regionally.

Young people judge most groups differently based on the level of qualification. Those with the highest level of qualification perceive Hungarians from the neighbouring countries, the majorities of the societies, the other nations, and the "deviant" groups as more sympathetic than their peers. Hungarians from Hungary, Gypsies, politicians, and church authorities are perceived more positively by those with the lowest level of qualification as compared to other groups based on the level of education.

The evaluation of certain social groups differs based on the young adults' occupation. Gypsies are perceived as more sympathetic by those who neither study nor work. The other ethnic groups, homosexuals, skinheads, and the upstart, are judged more positively by young adults who work and study.

The opinions of the youth from rural and urban settlements differ regarding most of the groups. Hungarians from Hungary, Slovakia, and Ukraine, politicians, church authorities, and Gypsies are more sympathized by rural dwellers while other groups by the urban ones. 
Age makes a significant difference only in the perception of a few groups, so that there are no generational gaps in attitudes towards otherness. Similarly to age, differences based on gender can be found in the case of only a few groups. Differences are the most accentuated in the perception of homosexuals, i.e. men sympathize more with drug consumers and Russians, while women perceive more positively the other enumerated groups.

The poorer the respondents are, the more they sympathize with the Gypsies. The relatively poor young people perceive the upstart as antipathetic. The other groups are more liked by those living in favourable material conditions.

The tendencies from the comparison of means are not univocal enough referring to the socio-demographic background. The hypothesis of projection or scapegoat - according to which the rural youth coming from a less favourable material and cultural background show a more negative attitude towards other groups than their peers - was not confirmed. For instance, rural dwellers with a lower level of education and less favourable material situation sympathize more with Gypsies. The groups perceived as deviant by the society are judged more positively by urban dwellers that work and study and have a higher level of education.

\section{Prejudices Based on Religiosity, Media Consumption, Political Orien- tation, Value System, Experiences from Abroad, and Experiences with Discrimination (H2-H6)}

The connection between institutional religiosity and tolerance has been hypothesized. Belonging to a denomination is not connected significantly with the sympathy thermometer; thus, the contradictory results of Murányi (1999) can neither be confirmed nor infirmed among the studied youth. Those who follow the rules of the church perceive otherness more sympathetic in general. So, religious observance and the preference of religious values favour sympathy towards otherness. At the same time, religiosity is connected to the level of education; therefore, those with a higher level of education are overrepresented among both who follow the rules of the church and the atheists. The impact of the two variables (level of education, religiosity) will be analysed in the explanatory model.

Based on Melican and Nixon's approach (2008), it was hypothesized that online sources favour selective perception. The results can neither confirm nor infirm that printed and online media consumption is connected to greater openness or that it favours selective perception.

Requesting Hungarian citizenship is connected to the perception of certain groups. The majority of the 14 groups are more sympathized by those who claimed Hungarian citizenship. Exceptions are Romanians, Gypsies, and Hungarians from Slovakia. The differentiating power of double citizenship was analysed in regional 
samples, too. Majority nations are more sympathized by those young adults from Ukraine and Transylvania who did not claim double citizenship.

Political interest and satisfaction with democracy are connected only to the perception of a few social groups, and the correlation coefficients indicate poor relations. Young adults who are less satisfied with democracy perceive otherness as more unappealing.

Self-placement on the political left-right scale seems to be more strongly connected to the perception of otherness. Rightist youth sympathize less with majority nations and with groups perceived as deviant. Rightists - who have probably a stronger national identity than their peers - sympathize more with Hungarians from Hungary and the neighbouring countries as well as with church authorities. They perceive all other groups as more unappealing than their peers.

The approach of the contact hypothesis tested by Chen - according to which the experiences from abroad favour the perception of otherness (Chen 2007: 7071) - was analysed among Hungarian youth from the neighbouring countries as well. Those who have accumulated both study and work experience sympathize less with Hungarians from Hungary. Those who studied or studied and worked abroad sympathize more with Jews, Hungarians from the neighbouring countries, refugees/migrants, homosexuals, drug consumers, and Russians. Thus, it seems that the study experience accumulated in another culture as well as the study and work experiences together are connected with a more positive relation to otherness.

More than half of the youth studied or worked in Hungary. More than $75 \%$ of those who named the country where they had studied earned experience in Hungary. Those who studied in Hungary perceive Hungarians from Hungary as significantly less sympathetic; therefore, the simplified version of the contact hypothesis was infirmed in their case. $40.7 \%$ of those who mentioned the countries where they had worked were in Hungary. Those who studied in Hungary sympathize more with Hungarians from the neighbouring countries as well as with Jews, Russians, homosexuals, and drug consumers. Those who have accumulated work experience in Hungary sympathize less with Romanians, refugees/migrants, homosexuals, and skinheads, but they perceive Hungarians from Ukraine and Gypsies as more sympathetic. It seems that the study and work experiences lead to different attitudes regarding homosexuals, but other factors may also play a role in this question.

The author assumed that negative experiences related to minority status and experiencing negative discrimination because of nationality enhance solidarity with other minority groups. $53 \%$ of the youth have this kind of experience. It seems that those who have experienced discrimination perceive Hungarians more positively and other groups more negatively, so that solidarity emerges selectively related to their own ethnic group. The way majority nations are perceived is probably also due to their discriminative actions experienced by the youth due to their national identity. The standard deviation is the highest in the case of Gypsies, and those 
who have been discriminated perceive Gypsies as more unappealing. In this case, it is not very feasible that they have experienced discrimination from Gypsies. A more plausible explanation could be the reverse effect of the Gypsy-supporting discourses present in the public sphere.

In order to develop explanatory models for testing the hypotheses, aggregated indicators were needed from the previously analysed variables.

\section{Model-Building Attempt for the System of Prejudices}

Using the socio-demographic variables and the other factors formulated in the hypotheses, we tried to explain the attitude towards the groups perceived as being deviant. Among the previous works in the literature, we can read about approaches which define and mention homeless people, homosexuals, drug consumers, and skinheads as groups perceived by the public opinion as being deviant (Székelyi et al. 2001: 5). Similarly, Murányi analyses drug consumers, skinheads, and homosexuals as groups which can be characterized by deviance (Murányi 1999). Starting from these, the groups perceived as the most unappealing by the youth were included in one principal component: homosexuals, drug consumers, skinheads, and refugees/ migrants. A principal component was created from the groups perceived as being the most deviant.

Table 1. The principal component of the groups perceived as deviant (explained variance $54.8 \%$ )

\begin{tabular}{cc}
\hline Variables & Factor scores \\
\hline Homosexuals & 0.794 \\
\hline Drug consumers & 0.755 \\
\hline Skinheads & 0.720 \\
\hline Refugees/migrants & 0.687 \\
\hline
\end{tabular}

Source: author's computation based on the dataset of the GeneZYs 2015 study

Certain factors contribute to a small extent to the explanation of prejudices. Those who consider success and goal achievement as being important proved to be more prejudicial, and, inversely, those who are less success-oriented are more tolerant towards otherness. Those who support the legalization of soft drugs and marriage between homosexuals sympathize more with the groups perceived by the public opinion as deviant. Those who support the limitation of citizens' rights when fighting terrorism and who expect from migrants to accept and adapt to local culture can be characterized by antipathy towards homosexuals, drug consumers, skinheads, and refugees/migrants.

The older the respondents are, the more probably they perceive the above mentioned groups as sympathetic. Those with a low level of education act more 
tolerant with the groups perceived as deviant. The more rightist the respondents identify themselves politically, the more they evaluate the so-called deviant groups as antipathetic. Sympathy regarding politicians, the upstart, the Gypsies, and other nations shows a strong correlation with sympathy towards the enumerated groups. Tolerance towards other groups determines the acceptance of the groups perceived as deviant. Those who have better English language skills are more acceptant towards groups perceived as more unappealing by the majority.

Therefore, it seems that material situation, settlement type, religiosity, media consumption from printed and online sources, the heterogeneity of Facebook friends, and ethnic discrimination are not in causal relation with the perception of the least sympathetic group.

Tables 2 and 3 present the results of the regression analysis in terms of sympathy towards the groups perceived as deviant. The dependent variable was the principal component presented in Table 1. The independent variables were: year of birth, level of qualification, English language skills, self-placement on the political leftright scale, and principal components created from other nations (Chinese, Jews, Germans, Americans, Russians), the second ungrateful group (politicians, newly rich, Gypsies), legalization (of soft drugs and marriage of homosexuals), restrictions (expectations from migrants to accept the culture, values of the receiving country and limitation of citizens' right when fighting terrorism), and success orientation (five values were included: 1 . to be able to take, buy what you want; 2 . to reach your objectives; 3 . success, 4 . the right to conduct, to decide; 5 . money).

Table 2. Sympathy towards the group perceived as deviant - linear regression model (explained variance $37.6 \%$ )

\begin{tabular}{lc}
\hline \multicolumn{1}{c}{ Variables } & Beta \\
\hline success-oriented & $-0.120^{* * *}$ \\
\hline legalization & $0.346^{* * *}$ \\
\hline restriction & $-0.080^{* *}$ \\
\hline year of birth & $-0.080^{*}$ \\
\hline sympathy for other nations & $0.222^{* * *}$ \\
\hline sympathy for the second ungrateful group & $0.234^{* * *}$ \\
\hline self-placement on the political left-right scale & $-0.095^{* * *}$ \\
\hline English language skills & $0.130^{* * *}$ \\
\hline qualification & $-0.090^{*}$ \\
\hline
\end{tabular}

Level of significance: ${ }^{* *} \mathrm{p}<0.001,{ }^{* *} \mathrm{p}<0.01,{ }^{*} \mathrm{p}<0.05$

Source: author's computation based on the dataset of the GeneZYs 2015 study

Analysing the question on the regional level shows (Table 3) that if the regional differences are included in the model, the explained variance will somewhat increase, but age, level of education, and English language skills will be lost as 
explanatory factors. Thus, in this model, the youth from Ukraine and Slovakia perceive the so-called groups as much more unappealing than their peers.

Table 3. Sympathy for the deviant group - linear regression model (explained variance $40.5 \%$ )

\begin{tabular}{lc}
\hline \multicolumn{1}{c}{ Variables } & Beta \\
\hline success-oriented & $-0.132^{* * *}$ \\
\hline legalization & $0.335^{* * *}$ \\
\hline restriction & $-0.072^{* *}$ \\
\hline relation to other nations & $0.211^{* * *}$ \\
\hline relation to the second ungrateful group & $0.224^{* * *}$ \\
\hline self-placement on the political left-right scale & $-0.075^{* *}$ \\
\hline Ukraine & $-0.191^{* * *}$ \\
\hline Slovakia & $-0.175^{* * *}$ \\
\hline
\end{tabular}

Level of significance: ${ }^{* *} \mathrm{p}<0.001,{ }^{* *} \mathrm{p}<0.01,{ }^{*} \mathrm{p}<0.05$

Source: author's computation based on the dataset of the GeneZYs 2015 study

In the regression model, opinions in support of legalizing soft drugs and marriage between homosexuals played the role of the most decisive factor.

\section{Attempt at Creating a Typology}

I have tried to identify types with cluster analysis based on the attitudes towards the social groups organized into principal components. We identified three main types difficult to interpret: a group which considers everybody appealing with a small number of cases, a neutral one which perceives their own communities as less sympathetic with a large number of cases, and a third one that considers otherness as unappealing with a medium number of cases.

Men, rural dwellers, those with a medium level of education, the economically active, the youth in Ukraine, the atheists, those who did not study abroad, who experienced discrimination, who have regional Hungarian and/or Hungarian identity, who are not satisfied with the economic situation of the country as well as with the interethnic relations, and who think pessimistically about the future are overrepresented among those who perceive otherness as unappealing. Tables 6 and 7 from the Appendix present the characteristics of the cluster groups and cluster centres. 


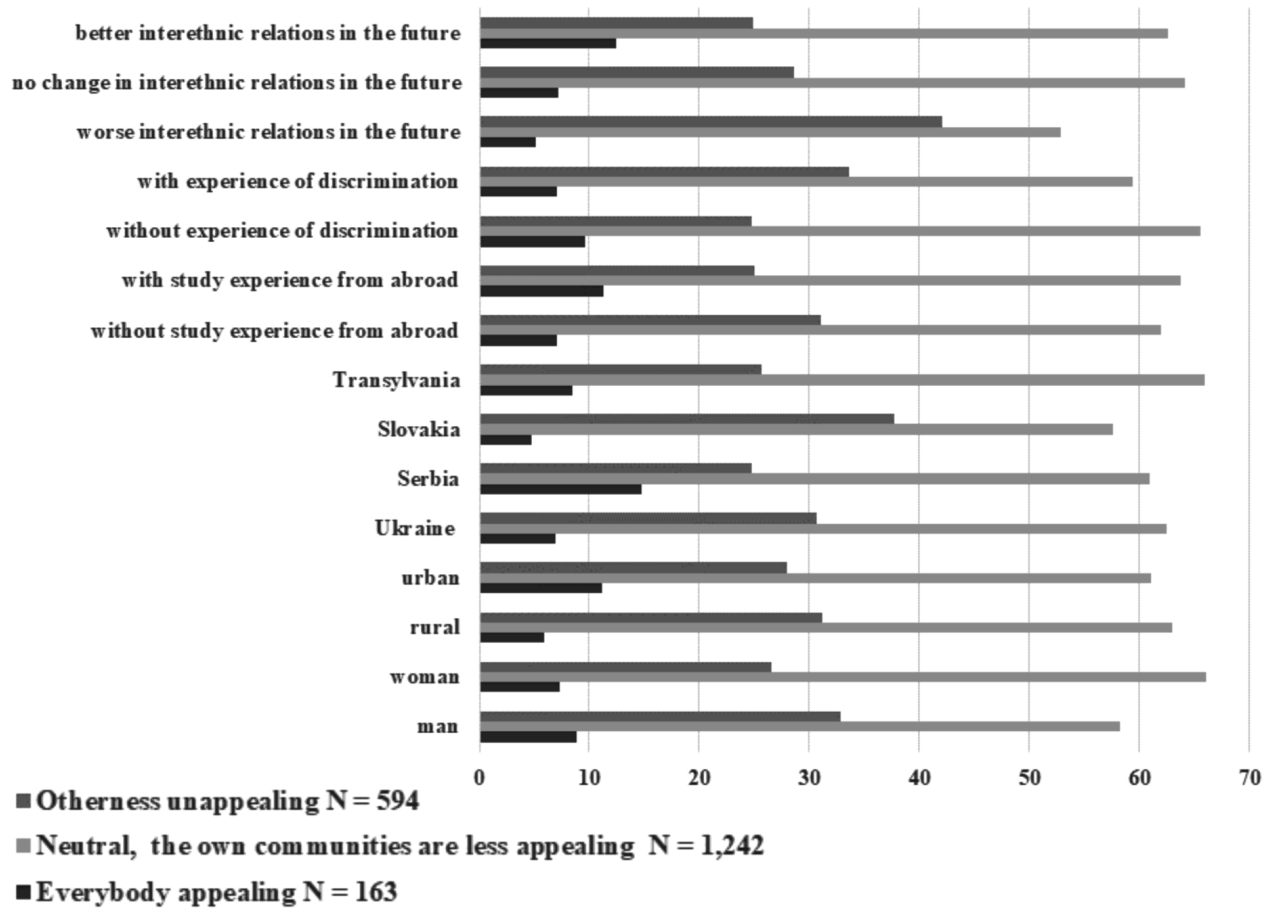

Source: author's computation based on the dataset of the GeneZYs 2015 study

Figure 2. Characteristics of the cluster groups based on the sympathy "thermometer"

The group which perceives everybody as appealing can be characterized by a more favourable income situation than others. This seems to contradict the result that the economically active are overrepresented among those who perceive otherness as unappealing; however, this variable should be treated carefully as it includes not only their own money but also the received allowances. The created types differ from the point of view of the state language and English language skills. Preference of the Hungarian as a value is connected with rejection of otherness. The heterogeneity of Facebook friends and the existence of a higher proportion of majority young people among their acquaintances are more characteristic in the group which sympathizes with otherness. 
Table 4. Characteristics of the cluster groups based on the sympathy "thermometer" (significant relations, means)

\begin{tabular}{|c|c|c|c|c|c|}
\hline & & $\begin{array}{c}\text { Total } \\
\text { sample } \\
N=1,999\end{array}$ & $\begin{array}{c}\text { Everybody } \\
\text { appealing } \\
\mathrm{N}=163\end{array}$ & $\begin{array}{c}\text { Neutral, the own } \\
\text { communities are } \\
\text { less appealing } \\
\mathrm{N}=1,242\end{array}$ & $\begin{array}{c}\text { Otherness } \\
\text { unappealing } \\
\mathbf{N}=\mathbf{5 9 4}\end{array}$ \\
\hline \multirow{2}{*}{$\begin{array}{l}\text { Foreign language skills } \\
(1-\text { not at all, } 6 \text { - mother } \\
\text { tongue) }\end{array}$} & State language & 4 & 4.4 & 4 & 3.8 \\
\hline & English & 2.9 & 3.4 & 2.8 & 2.7 \\
\hline $\begin{array}{l}\text { National values } \\
(1-\text { not at all, } 5 \text { - very } \\
\text { important) }\end{array}$ & $\begin{array}{l}\text { Hungarian as } \\
\text { identity }\end{array}$ & 4 & 3.9 & 3.9 & 4.1 \\
\hline $\begin{array}{l}\text { Functioning of democracy } \\
\text { (1- unsatisfied, } 10- \\
\text { satisfied) }\end{array}$ & Satisfaction & 4.3 & 4.5 & 4.4 & 3.9 \\
\hline $\begin{array}{l}\text { Self-placement } \\
(1-\text { left, } 7 \text { - right })\end{array}$ & Political & 4.6 & 4.4 & 4.4 & 5 \\
\hline \multirow{2}{*}{$\begin{array}{l}\text { Composition of Facebook } \\
\text { acquaintances (\%) }\end{array}$} & Hungarian & 75 & 68 & 75 & 76 \\
\hline & Majoritarian & 21 & 26 & 20 & 20 \\
\hline
\end{tabular}

Source: author's computation based on the dataset of the GeneZYs 2015 study

I have tried to explain the types with the help of the functions determined by social status and opinions-competences (tables 5-13 can be found in the Appendix). The monthly income and the principal component created from the religious values played the role of status variables. On one pole of the line of the first function, there are those characterized by a favourable material situation, high income, and a lower level of religiosity, while on the other pole there are the religious youth with less favourable material situation. The other function is similar to the first one, and its capacity to discriminate is lower; its range covers the section between religious young adults with moderate financial status and their non-religious peers with extreme financial situation. The main difference between the two functions is that the first one is more strongly determined by the financial situation while the second one by religiosity.

Among the groups delimited based on the sympathy thermometer, those with higher income sympathize more with all other groups, while the less religious youth perceives otherness as more unappealing.

The results show that $46.5 \%$ of the cases can be successfully classified by this function. The explained variance is not so high, but it is still better than estimating with the modus, without the discriminant function.

The function of opinions and competences was formed by five elements: the first and the third ones are principal components. The first one includes the opinions regarding the legalization of soft drugs and marriage between homosexuals; the second one includes the self-placement on the political left-right scale; the third one contains opinions referring to the limitation of citizens' rights; the fourth one 
comprises the work experience from Hungary; the last one includes the English language skills. The first function is strongly determined by the rejection of legalization, rightist political orientation, and limitation of citizens' rights. Thus, on one end of the line, there are placed those who would not legalize soft drugs and marriage between homosexuals, the rightist young people who would support the limitation of citizens' rights when fighting terrorism, who would expect from the migrants to accept our culture, and who do not speak English well. On the other end of the line, there are the young adults with opposite opinions, who speak English better. The other function is strongly determined by work experience from Hungary, English language competences, and self-placement on the political left-right scale. On one end of the line, there are the rightist young people who have worked in Hungary, who speak English better, and who agree both with legalization and the limitation of rights, while on the other end the leftist young people are placed who have not worked in Hungary, have a poorer command of English, and do not agree with either legalization or limitation. Rightist political orientation is a determining factor of both functions; the composition of functions is quite heterogeneous, but these opinions do not exclude each other.

The rightist youth who do not support legalization and who would prefer the limitation of citizens' rights perceive otherness as unappealing, while those less rightists who support legalization and oppose limitation judge each group as more appealing. Young adults who speak English and have worked in Hungary perceive each group as more appealing.

Thus, $44.2 \%$ of the cases were classified successfully, which is less than the explained variance of the former function but significantly more than the modus.

By including the four discriminant functions in the analysis, two more functions were formed. On one pole of the first function, there are the rightists, non-religious youth who do not support legalization, who prefer limitation, who speak English less well and have lower income. On the other pole, there are the young people who have worked in Hungary, can speak English better, have higher income, and have more liberal attitudes. The determining elements of the second function are language competences, work experience in Hungary, and favourable material situation. On one end of the line, there are the less religious youth with higher income, good English skills, with work experience in Hungary, while on the other end the religious ones with lower income, poor English skills, and no work experience in Hungary.

The created two functions indicate that those who perceive otherness as unappealing do not prefer liberal values and are less religious, while young adults who have higher incomes, better English skills, and work experience in Hungary judge each group as more sympathetic. Based on these results, the affective component of the attitudes can be partially explained by opinions, certain elements of the social background, and certain competences. All in all, $42.6 \%$ of the cases were successfully classified with the two functions. 


\section{Conclusions}

The hypotheses were only partially confirmed or infirmed based on the results. Connections were successfully proved regarding the variables mentioned in the hypotheses, but there is much room for improvement when it comes to building up the explanatory model and the type creation results.

The results show that there can be found regional differences among the youth. However, it can be affirmed only carefully that Hungarian young people from the analysed countries behave themselves more open towards otherness. It seems that young people from Serbia are the most tolerant, but further analyses, evidence, and explanatory models would be needed in order to support this affirmation.

The relation of the youth with otherness cannot be constrained between the frames formed by the hypotheses, i.e. the socio-demographic background, religiosity, value preferences, relation to politics, and media consumption do not determine the attitudes towards other groups. At the same time, one can read these types of tendencies and explanations in the literature. Thus, it remains a question whether the models confirmed in the case of the adult generation are less sustainable in the case of new generations, or the author's competences limit the analysis and explanation of the results.

One of the possible explanations which can be outlined from the results of the present analysis is that similarly to the Hungarian adult population, where there is a consensus regarding hostility to Gypsies (e.g. Székelyi et al. 2001) and about the fact that anti-Semitism cannot be described by characteristics of social background (Balassa 2007, Kovács 2014, Hann-Róna 2015), the attitudes of the Hungarian youth from the neighbouring countries towards otherness cannot be sufficiently explained by hard indicators. The hypotheses probably should be reformulated, and a future study should concentrate on softer variables such as communication topics in socialization environments. The author considers that family, school, and peer group continuously play - to various extents - the role of pattern transmission in forming the attitudes of the youth, but their effect does not emerge through cultural, material background, settlement type, etc. but through the content of interactions. In order to explore the latter ones, qualitative methods seem to be necessary besides quantitative tools. One has to pay attention to several dimensions of prejudice both with quantitative and qualitative methods besides the affective component of the attitudes: the antecedents from the literature offer patterns in this sense.

The differentiated analysis of the impact of context and contact could be a proposal of a further research, in which the paper of Balassa and Kovács (2010) can represent the starting-point. Thus, the independent and connected effects can be measured. For this reason, the delimitation of heterogeneous and homogenous settlements is necessary in the sample as well as a more targeted inclusion of contacts in the analyses. 
In order to analyse the role of the minority status - as a factor of enhancing solidarity towards otherness -, a comparison with majority and Hungarian young people would be extremely needed.

Therefore, certain narrower segments of the socio-demographic background still explain partially the affective component of the attitudes, but they do not offer enough tools to draw the profile of young adults who accept or reject otherness. Probably, a diversity and complexity of profiles characterizes all of the young people belonging to the three groups (acceptance, neutral behaviour, and rejection).

\section{References}

Bădescu, Gabriel, Comşa, Mircea, Gheorghiță, Andrei, Stănuş, Cristina, Tufiş, D. Claudiu. 2010. Implicarea civică şi politică a tinerilor. Constanța: Dobrogea.

Balassa, Szilvia. 2007. Antiszemiták, cigányellenesek, xenofóbok. In: Bakó, B., Papp, R., Szarka, L., (eds.), Tér és terep 5. Tanulmányok az etnicitás és az identitás kérdésköréböl. Budapest: Balassi. 205-240.

Balassa, Szilvia, Kovács, András. 2010. Kontextus és kontaktus. A kontaktushipotézis vizsgálata magyarországi vegyes lakosságú településeken. Alkalmazott Pszichológia XII (1-2): 99-112.

Beréti, László, Tóth, Csaba. 2014. A magyar társadalom és az előítéletesség. Hadtudományi Szemle 7(2): 95-105.

Csata, István, Kiss, Tamás. 2007. Népesedési perspektívák. Cluj-Napoca: Kriterion.

Chen, Dania 2007. Changes in Social Distance among American Undergraduate Students Participating in a Study Abroad Program in China. Dissertation prepared for the degree of Doctor of Philosophy. University of North Texas.

Csepeli, György, Fábián, Zoltán, Sik, Endre. 2006. Xenofóbia és a cigányságról alkotott vélemények. Available at: www.tarki.hu/adatbank-h/kutjel/pdf/a881. pdf.

Erős, Ferenc. 2005. Az elő́télet-kutatás dilemmái. In: Neményi, M., Szalai, J. (eds.), Kisebbségek kisebbsége. A magyarországi cigányok emberi és politikai jogai. Budapest: Új Mandátum. 353-375.

2007. Irányok és tendenciák az előítéletek kutatásában. Educatio 16(1): 3-9.

Erőss, Gábor, Gárdos, Judit. 2007. Az előítéletesség-kutatások bírálatához. Educatio 16(1): 307-322.

Fábián, Zoltán, Erős, Ferenc. 1996. Autoritarizmus és társadalmi tényezők a cigányellenesség magyarázatában. In: Erős, F. (ed.), Azonosság és különbözôség. Tanulmányok az identitásról és az elôítéletról. Budapest: Scientia Humana. 182-200.

Fábián, Zoltán, Sik, Endre. 1996. Előítéletesség és tekintélyelvúség. In: Andorka, R., Kolosi, T., Vukovich, Gy. (eds.), Társadalmi riport 1996. Budapest: TÁRKISzázadvég. 381-413. 
G. Márkus, György. 2012. Előítéletesség Európában, intolerancia Magyarországon. Recenzió és reflexió. XXI. Század-Tudományos Közlemények 27: 73-84.

Hann, Endre, Róna, Dániel. 2015. Antiszemita elöítéletesség a mai magyar társadalomban. Research report. Budapest. Available at: http://tev.hu/wp-content/ uploads/2014/04/Median_TEV_antiszemitizmus-tanulmany_2014_HU.pdf.

Kiss, Tamás, Barna, Gergő. 2013. Erdélyi magyarok a magyarországi és a romániai politikai térben. Múhelytanulmányok a romániai kisebbségekról 50. Cluj-Napoca: ISPMN.

Kiss, Tamás, Barna, Gergő, Sólyom, Zsuzsa. 2008. Erdélyi magyar fiatalok 2008. Műhelytanulmányok a romániai kisebbségekról 12. Cluj-Napoca: ISPMN.

Kovács, András. 2007. Lehet-e előítélet az előítélet? Educatio 16(1): 10-16.

2014. Zsidóellenes előítéletesség és az antiszemitizmus dinamikája a mai Magyarországon. In: Kolosi, T., Tóth, I. Gy. (eds.), Társadalmi riport 2014. Budapest: TÁRKI. 486-508.

Melican, Debra Burns, Nixon, Travis L. 2008. News on the Net. Credibility, Selective Exposure, and Racial Prejudice. Communication Research 35(2): 151-168.

Mihăilescu, Vintilă. 1996. Două sate în tranziție. Tipuri strategice dominante în lumea rurală. Revista de Cercetări Sociale 3: 3-24.

Milosevic Dordevic, Jasna. 2015. The Role of Contact in Reducing Social Distance of Youth from the Balkans towards Minority Groups. Primenjena Psihologija 8(4): 415-432.

Molnár, Viktória Gizella. 2011. A média hatása a 14-18 éves fiatalok előítéletességére. In: Balku, A., Dusa, Á., Sőrés, A. (eds.), Ifjúságszociológiai tanulmányok I. Ifjúsági élethelyzetek. Debrecen: Egyetemi Kiadó. 61-81.

Murányi, István. 1998. Szociokulturális és területi tényezők szerepe a 10-17 éves fiatalok elő́téletes gondolkodásában. In: Sik, E., Tóth, J. (eds.), Idegenek Magyarországon. MTA PTI Nemzetközi Migráció Kutatócsoport Évkönyve. Budapest: MTA PTI. 139-153.

2004. Fiatalok vallásos szocializációja és elóítéletessége. Educatio 13(4): 583594.

Murányi, István, Szabó, Ildikó. 2007. Középiskolások előítéletességének egy lehetséges magyarázata: az életforma. Educatio 16(1): 38-49.

Örkény, Antal, Váradi, Luca. 2010. Az előítéletes gondolkodás társadalmi beágyazottsága, nemzetközi összehasonlításban. Alkalmazott Pszichológia XII(12): 29-46.

Papp Z., Attila. 2008. Viszonyulások. Kis magyar (Kárpát-medencei) előítélettérkép. Kalligram 2: 70-76.

2012. Az etnocentrizmus szerkezete kisebbségben - a fókuszcsoportos beszélgetések alapján. In: Veres, V., Papp Z., Attila (eds.), Szociológiai mintázatok. Erdélyi magyarok a Kárpát-panel vizsgálatai alapján. Cluj-Napoca: Nemzeti Kisebbségkutató Intézet. 79-116. 
2014. Kisebbségi identitáskonstrukciók a kettős magyar állampolgárság által. Regio 22(1): 118-155.

Plăeşu, Ancuța, Dalu, Ana-Maria, Achimescu, Vlad. 2015. Discriminarea - factor de risc în incluziunea socială a tinerilor NEET. Bucharest: Pro Universitaria.

Shields, David Light. 2014. Deconstructing the Pyramid of Prejudice. Phi Delta Kappan 95(6): 20-24.

Sólyom, Andrea. 2007. Ifjúsági szubkultúrák és csoportfolyamatok Székelyudvarhelyen. In: Jakab, A. Zs., Keszeg, V. (eds.), Csoportok és kultúrák. Cluj-Napoca: KJNT. 101-131.

2009. Erdélyi fiatalok politikához való viszonyának kutatása közben felmerülő problémákról. Educatio 19(4): 519-524.

2011. Székelyudvarhelyi XI-XII. osztályos diákok értékpreferenciái. Reconect 3(1): 61-79.

2012. Értékorientációk, továbbtanulás, társadalmi távolságok. Manuscript.

2013. Politikai cselekvési minták középiskolások és egyetemisták körében. Pro Minoritate 22(2): 97-128.

Sőrés, Anett. 2012. A szélsőjobboldali egyetemisták mint virtuális csoport. In: Dusa, Á. R., Kovács, K., Márkus, Zs., Nyüsti, Sz., Sôrés, A. (eds.), Egyetemi élethelyzetek. Ifjúságszociológiai tanulmányok I. Debrecen: Egyetemi Kiadó. 191-218.

Székelyi, Mária, Örkény, Antal, Csepeli, György. 2001. Romakép a mai magyar társadalomban. Szociológiai Szemle 3: 19-46.

Szénási, Sándor. 2016. Gyilkos idők - A társadalom útja a romák elleni támadásokig. 168 óra. https://168ora.hu/itthon/gyilkos-idok-a-tarsadalom-utja-a-romak-ellenitamadasokig-8730.

Varga, Szabolcs. 2012. A debreceni egyetemisták és a szélsőjobb. A Campuslét-kutatás online adatbázisának kvantitatív elemzése. In: Dusa, Á. R., Kovács, K., Márkus, Zs., Nyüsti, Sz., Sőrés, A. (eds.), Egyetemi élethelyzetek. Ifjúságszociológiai tanulmányok I. Debrecen: Egyetemi Kiadó. 247-265.

Voicu, Bogdan. 2006. Introducere: pe drumul către şase sate. In: Voicu, B., Voicu, M. (eds.), Satul european pe drumul către Europa. Iaşi: Polirom. 15-28.

Zick, Andreas, Küpper, Beate, Hövermann, Andreas. 2011. Intolerance, Prejudice and Discrimination. A European Report. Berlin: Friedrich-Ebert-Stiftung.

\section{Audiovisual Materials}

AV1 = https://www.youtube.com/watch?v=1F8I2RUwi1w (27.03.2017).

AV2 = Szilágyi N., Sándor: Én ember szeretnék maradni, ha nem nagy baj. http:// www.maszol.ro/index.php/velemeny/68240-szilagyi-n-sandor-en-emberszeretnek-maradni-ha-nem-nagy-baj (27.03.2017).

AV3 = Tamás, Gáspár Miklós: Farsangi videó Oroszhegyról. http://tgm.transindex. ro/?cikk=1245 (27.03.2017). 


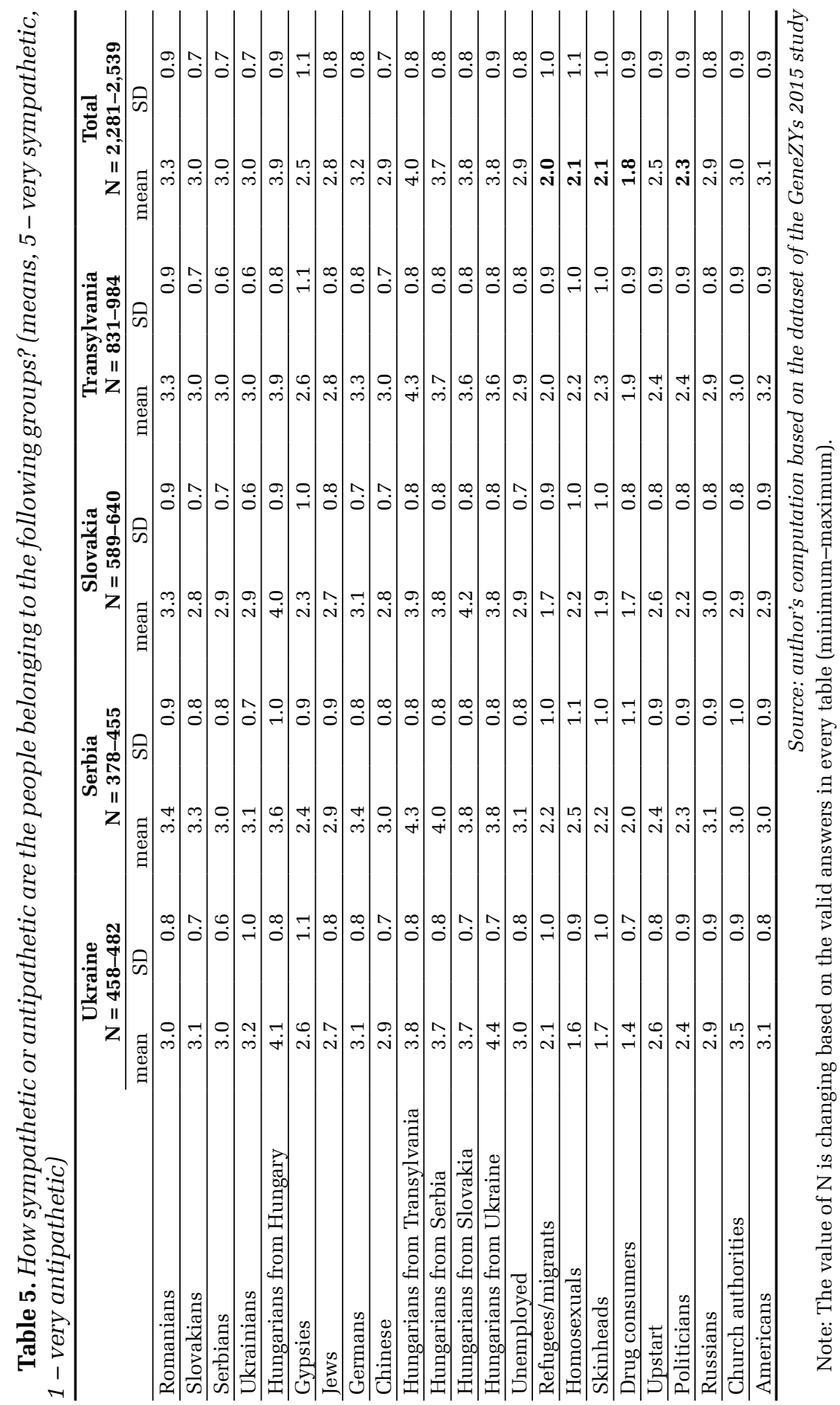


Table 6. Cluster groups created based on the sympathy "thermometer" (cluster centres)

\begin{tabular}{lccc}
\hline \multicolumn{1}{c}{ Variables } & $\begin{array}{c}\text { Everybody } \\
\text { appealing } \\
\mathbf{N = 1 6 7}\end{array}$ & $\begin{array}{c}\text { Neutral } \\
\mathbf{N = 1 , 2 9 8}\end{array}$ & $\begin{array}{c}\text { Otherness } \\
\text { unappealing } \\
\mathbf{N = 6 0 5}\end{array}$ \\
\hline Groups perceived as deviant & 1.09395 & 0.25731 & -0.77390 \\
\hline Hungarians from the neighbouring countries & 0.95159 & -0.26078 & 0.23915 \\
\hline Majority nations & 1.98069 & 0.04653 & -0.61837 \\
\hline Other nations & 1.81492 & 0.10494 & -0.73488 \\
\hline The second unappealing group & 1.05684 & 0.33774 & -0.98055 \\
\hline
\end{tabular}

Source: author's computation based on the dataset of the GeneZYs 2015 study

Table 7. Characteristics of the cluster groups based on the sympathy "thermometer" (significant relations, percentage per row)

\begin{tabular}{|c|c|c|c|c|}
\hline & & $\begin{array}{c}\text { Everybody } \\
\text { appealing } \\
\mathrm{N}=163\end{array}$ & $\begin{array}{l}\text { Neutral, } \\
\text { the own communities } \\
\text { are less appealing } \\
N=1,242\end{array}$ & $\begin{array}{c}\text { Otherness } \\
\text { unappealing } \\
\mathbf{N}=\mathbf{5 9 4}\end{array}$ \\
\hline \multirow[t]{2}{*}{ Gender } & man & 8.8 & 58.3 & 32.8 \\
\hline & woman & 7.3 & 66.1 & 26.5 \\
\hline \multirow[t]{2}{*}{ Settlement type } & rural & 5.9 & 63 & 31.2 \\
\hline & urban & 11.1 & 61.1 & 27.9 \\
\hline \multirow[t]{4}{*}{ Region } & Ukraine & 6.9 & 62.5 & 30.6 \\
\hline & Serbia & 14.7 & 60.9 & 24.8 \\
\hline & Slovakia & 4.7 & 57.6 & 37.7 \\
\hline & Transylvania & 8.4 & 65.9 & 25.7 \\
\hline \multirow[t]{3}{*}{ Qualification } & elementary & 6.9 & 67.6 & 25.5 \\
\hline & secondary & 7.3 & 58.8 & 34 \\
\hline & higher education & 10.9 & 63.6 & 25.5 \\
\hline \multirow[t]{4}{*}{ Occupation } & economically active & 8.3 & 57.9 & 33.8 \\
\hline & economically inactive & 7.7 & 63.6 & 28.7 \\
\hline & unemployed & 8.5 & 63.7 & 27.8 \\
\hline & student & 7.9 & 66.5 & 25.7 \\
\hline \multirow[t]{4}{*}{ Religiosity } & $\begin{array}{l}\text { he/she follows the } \\
\text { rules of the church }\end{array}$ & 9.8 & 67.2 & 23 \\
\hline & on his/her own way & 7.9 & 61.2 & 30.9 \\
\hline & not religious & 5.8 & 63.5 & 30.8 \\
\hline & atheist & 12.1 & 48.3 & 39.7 \\
\hline \multirow{2}{*}{$\begin{array}{l}\text { Study experience } \\
\text { from abroad }\end{array}$} & no & 7.1 & 61.9 & 31 \\
\hline & yes & 11.3 & 63.8 & 25 \\
\hline \multirow{2}{*}{$\begin{array}{l}\text { Experience of } \\
\text { discrimination }\end{array}$} & no & 9.6 & 65.6 & 24.8 \\
\hline & yes & 7 & 59.4 & 33.6 \\
\hline
\end{tabular}




\begin{tabular}{|c|c|c|c|c|}
\hline & & $\begin{array}{c}\text { Everybody } \\
\text { appealing } \\
N=163\end{array}$ & $\begin{array}{c}\text { Neutral, } \\
\text { the own communities } \\
\text { are less appealing } \\
\mathrm{N}=1,242\end{array}$ & $\begin{array}{c}\text { Otherness } \\
\text { unappealing } \\
\mathbf{N}=\mathbf{5 9 4}\end{array}$ \\
\hline \multirow[t]{8}{*}{ Primary identity } & regional & 9.8 & 61.4 & 28.8 \\
\hline & regional Hungarian & 8.4 & 61.4 & 30.3 \\
\hline & Hungarian & 4.2 & 58.8 & 37 \\
\hline & citizenships & 8.4 & 66.1 & 25.1 \\
\hline & inner region & 7.4 & 61.8 & 30.9 \\
\hline & country & 7.7 & 72.3 & 20 \\
\hline & European & 14.1 & 57.8 & 28.1 \\
\hline & other & 7 & 71.9 & 21.1 \\
\hline \multirow{3}{*}{$\begin{array}{l}\text { Economic } \\
\text { situation in the } \\
\text { last ten years }\end{array}$} & worse & 6.8 & 66.8 & 26.4 \\
\hline & no change & 6.8 & 66.8 & 26.4 \\
\hline & better & 10.7 & 62.2 & 27.1 \\
\hline \multirow{3}{*}{$\begin{array}{l}\text { Standard of } \\
\text { living in the last } \\
\text { ten years }\end{array}$} & worse & 7.6 & 59 & 33.4 \\
\hline & no change & 8.5 & 66.2 & 25.2 \\
\hline & better & 7.0 & 62.8 & 30.2 \\
\hline \multirow{3}{*}{$\begin{array}{l}\text { Personal } \\
\text { situation in the } \\
\text { last ten years }\end{array}$} & worse & 9.4 & 54.2 & 36.4 \\
\hline & no change & 7.0 & 65.7 & 27.3 \\
\hline & better & 8.3 & 62.7 & 29 \\
\hline \multirow{3}{*}{$\begin{array}{l}\text { Interethnic } \\
\text { relations in the } \\
\text { last ten years }\end{array}$} & worse & 4.8 & 53.9 & 41.4 \\
\hline & no change & 8.1 & 66.2 & 25.7 \\
\hline & better & 12.4 & 61.8 & 25.8 \\
\hline \multirow{3}{*}{$\begin{array}{l}\text { Economic } \\
\text { situation in the } \\
\text { future }\end{array}$} & worse & 6.2 & 55 & 38.8 \\
\hline & no change & 6.4 & 67.6 & 26 \\
\hline & better & 12.7 & 61.9 & 25.4 \\
\hline \multirow{3}{*}{$\begin{array}{l}\text { Standard of } \\
\text { living in the } \\
\text { future }\end{array}$} & worse & 6.1 & 57 & 36.9 \\
\hline & no change & 7.1 & 65.8 & 27.1 \\
\hline & better & 11.9 & 63.1 & 25.1 \\
\hline \multirow{3}{*}{$\begin{array}{l}\text { Personal } \\
\text { situation in the } \\
\text { future }\end{array}$} & worse & 5.5 & 51.6 & 42.9 \\
\hline & no change & 7.3 & 63.4 & 29.3 \\
\hline & better & 9.3 & 63.5 & 27.2 \\
\hline \multirow{3}{*}{$\begin{array}{l}\text { Interethnic } \\
\text { relations in the } \\
\text { future }\end{array}$} & worse & 5.1 & 52.8 & 42.1 \\
\hline & no change & 7.2 & 64.1 & 28.6 \\
\hline & better & 12.5 & 62.6 & 24.9 \\
\hline
\end{tabular}

Source: author's computation based on the dataset of the GeneZYs 2015 study

Table 8. Status functions. Discrimination analysis, structure matrix

\begin{tabular}{lcc}
\hline & $\mathbf{1}$ & $\mathbf{2}$ \\
\hline Monthly income & 0.932 & 0.363 \\
\hline Religious values & -0.489 & 0.872 \\
\hline
\end{tabular}


Table 9. The position of groups delimitated based on prejudices on the status functions

\begin{tabular}{lcc}
\hline & High income & Religiosity \\
\hline Everybody appealing & 0.329 & 0.066 \\
\hline Neutral, the own communities are less unappealing & -0.050 & 0.045 \\
\hline Otherness unappealing & 0.012 & -0.111 \\
\hline
\end{tabular}

Source: author's computation based on the dataset of the GeneZYs 2015 study

Table 10. Functions determined by opinions and competences. Discrimination analysis, structure matrix

\begin{tabular}{lcc}
\hline & $\mathbf{1}$ & $\mathbf{2}$ \\
\hline Legalization (drugs and homosexuals) & $-0.702^{*}$ & 0.395 \\
\hline Self-placement on the political left-right scale & $0.599^{*}$ & 0.525 \\
\hline Limitation of citizens' rights & $0.520^{*}$ & 0.237 \\
\hline Work experience from Hungary & -0.072 & $0.574^{*}$ \\
\hline English language skills & -0.212 & $0.529^{*}$ \\
\hline
\end{tabular}

Source: author's computation based on the dataset of the GeneZYs 2015 study

Table 11. The position of groups delimitated based on prejudices on the functions of opinions and competences

\begin{tabular}{lcc}
\hline & $\begin{array}{c}\text { Rightist, against legalization, } \\
\text { pro-limitation }\end{array}$ & $\begin{array}{c}\text { Worked in Hungary, good } \\
\text { English skills, rightists }\end{array}$ \\
\hline Everybody appealing & -0.541 & 0.379 \\
\hline $\begin{array}{l}\text { Neutral, the own communities less } \\
\text { sympathetic }\end{array}$ & -0.104 & -0.111 \\
\hline Otherness unappealing & 0.378 & 0.107 \\
\hline
\end{tabular}

Source: author's computation based on the dataset of the GeneZYs 2015 study

Table 12. The functions determined by the status and opinions-competences. Discrimination analysis, structure matrix

\begin{tabular}{lcc}
\hline & $\mathbf{1}$ & $\mathbf{2}$ \\
\hline Rightist, against legalization, pro-limitation & $0.882^{*}$ & -0.016 \\
\hline Religiosity & $-0.276^{*}$ & -0.137 \\
\hline Worked in Hungary, good English skills, rightists & -0.161 & $0.766^{*}$ \\
\hline High income & -0.147 & $0.643^{*}$ \\
\hline
\end{tabular}

Source: author's computation based on the dataset of the GeneZYs 2015 study 
Table 13. The position of groups delimitated based on prejudices on the functions of opinions and the status

\begin{tabular}{lcc}
\hline & Not liberal, not religious & Favourable situation \\
\hline Everybody appealing & -0.463 & 0.347 \\
\hline Neutral, the own communities less sympathetic & -0.088 & -0.088 \\
\hline Otherness unappealing & 0.311 & 0.089 \\
\hline \multicolumn{2}{c}{ Source: author's computation based on the dataset of the GeneZYs 2015 study }
\end{tabular}

